\title{
ОРГАНІЗАЦІЙНО-ЕКОНОМІЧНИЙ МЕХАНІЗМ РОЗВИТКУ БІЗНЕС-СУБЕКТІВ АГРАРНОГО ВИРОБНИЦТВА
}

\author{
Крюкова Ірина Олександрівна \\ доктор економічних наук, доцент \\ Одеський державний аграрний університет (м.Одеса, Україна) \\ ORCID: 0000-0002-0577-6364 \\ kryukovaia1@rambler.ru
}

У статті розглянуто існуючі методичні підходи до трактування змісту категорії «організаційно-економічний механізм». Запропоновано визначення сутності організаційно-економічного механізму розвитку аграрних бізнес-суб'єктів. Доповнено склад основних елементів організаційно-економічного механізму в розрізі блоків внутрішнього та зовнішньогосподарського економічного механізму. Проведена загальна оцінка сучасного стану розвитку аграрного сектору, досліджено динаміка кількості агроформувань, рівень концентрації аграрного капіталу, результативності господарської діяльності. Висвітлено сучасні тенденції капіталізації агробізнесу, які проявляються у збільшенні кількості та масштабів бізнесу вітчизняних агрохолдингів. Визначено основні напрями удосконалення управління бізнес-суб'єктами у призмі дії складових організаційно-економічного механізму їх розвитку.

Ключові слова: організаційно-економічний механізм, аграрний бізнес, бізнес-суб'єкти, агрохолдинги, сільське господарство, сільські території, вартість аграрного бізнесу.

DOI: https://doi.org/10.32845/bsnau.2019.1.1

Постановка проблеми. Успішний розвиток вітчизняного аграрного виробництва в умовах додаткових можливостей і загроз, які формує активізація євроінтеграційних процесів, зумовлює необхідність створення механізму господарських відносин в ссрері аграрного виробництва, який сьогодні стане базисом реалізації як економічних інтересів аграрного бізнесу, так і відродження сільських територій.

Розвиток вітчизняного агробізнесу супроводжують чисельні проблеми, зумовлені як об'єктивними, так і суб'єктивними факторами загального стану розвитку національної економіки. Найважливішими серед них є: недосконалість фінансово-кредитної та податкової систем, нерозвиненість прозорої інфраструктури аграрного ринку, відсутність цінової еквівалентності обігу в різних сфрерах АПВ, необхідність завершення земельної реформи, низький економічний інтерес працівників аграрного сектора та незадовільні показники розвитку сільських територій. Вирішення цих найважливіших для агросфрери проблемних завдань в значній мірі акумулюється у призмі формування та дії організаційно-економічного механізму розвитку бізнес-суб'єктів аграрного сектору.

Аналіз останніх досліджень і публікацій. Проблема формування та удосконалення організаційно-економічного механізму функціонування сучасних аграрних бізнессуб'єктів $є$ надзвичайно широкою і комплексною сферою економічних досліджень, якій приділяється багато уваги в працях відомих вчених. Теоретичні, методичні та прикладні аспекти економічного механізму господарювання в ринкових умовах широко висвітлені в роботах Андрійчука В.Г., Амбросова В.Я., Дем'яненка М.Я., Зіновєва Ф.В., Коваленка Ю.С., Лупенка Ю.О., Маліка М.Й., Месель-Веселяка В.Я., Пархомця М.К., Полтавського Ю.А., Постола А.А., Саблука П.Т., Стельмащука А.М., Ушачова І.Г. та ін.

Поряд $з$ цим, висока ступінь динамічності умов економічного середовища, зростання конкурентних ризиків та специфіка розвитку аграрного сектору вимагають постійного удосконалення методичних аспектів та практичних засад реалізації механізмів розвитку бізнес-суб'єктів аграрної сфрери, які би забезпечили вирішення стратегічних завдань українського

села - підвищення рівня конкурентоспроможності сільського господарства та розв'язання проблем розвитку сільських територій. На сьогоднішній день у науковців відсутній єдиний погляд на сутність та склад організаційно-економічного механізму, що потребує подальшого опрацювання даної науковопрактичної проблеми.

Постановка завдання. Метою статті є обґрунтування теоретико-методичних засад організаційно-економічного механізму розвитку аграрних бізнес-суб'єктів та оцінка загального стану розвитку підприємств сільського господарства.

Виклад основного матеріалу дослідження. Ринкові умови господарювання реалізуються на практиці через призму дії сукупності законів, принципів, важелів та механізмів, завдяки яким суб'єкти економічних відносин досягають своїх цілей і завдань. Стосовно визначення сутності та змісту організаційно-економічного механізму розвитку бізнес-структур у теорії сфрормувались декілька методичних підходів. Так, певне коло вчених трактують організаційно-економічний механізм з позицій наявних цілей і стимулів, які дозволяють перетворити сукупність виробничих ресурсів на кінцевий результат $[7,5]$. 3 позицій процесного підходу організаційно-економічний механізм вчені визначають як сукупність організаційних, економічних, правових, управлінських і регулюючих дій, способів і процесів, необхідних для досягнення бажаного результату $[9,6]$.

Найбільш поширеним серед науковців $є$ системний підхід, який передбачає наявність та органічне поєднання його складових елементів. 3 точки зору системного підходу тлумачить зміст організаційно-економічного механізму Бутенко В. М.: «... сукупність систем, що сприяють узгодженню економічних інтересів учасників господарських відносин». [1]. Як систему технологічного, економічного, організаційного блоків, які включають до себе їх елементи, трактує дану дефініцію О. А. Єрьоменко - Григоренко [4]. 3 позиції системи організаційних, економічних, правових, управлінських і регулюючих дій, способів та прийомів, які впливають на показники діяльності аграрного підприємства, досліджує організаційноекономічний механізм Ткачук В.І. [15].

Вісник Сумського національного аграрного університету

Серія «Економіка і менеджмент», випуск 1 (79), 2019 
Поряд із певними відмінностями у трактуванні сутності організаційно-економічного механізму більшість вчених погоджуються, що ключовою складовою організаційно-економічного механізму розвитку бізнес-суб'єктів $є$ саме економічний механізм господарювання. На думку А.М. Стельмащука, економічний механізм включає:

1) механізм збалансованого розвитку агропромислового виробництва;

2) механізм розвитку і удосконалення товарно-грошових відносин;

3) механізм гармонійного поєднання економічних інтересів учасників [13].

Т.Л. Мостенська дотримується точки зору, згідно якої зміст категорії "економічний механізм" можна визначити як механізм реалізації політики держави, який за допомогою використання державних важелів регулювання спрямовує дію ринкових законів в необхідному для держави напрямі, або це механізм впливу державного регулювання на дії ринкових законів з метою досягнення поставлених цілей [8]. Домахіна $€$.В. у своїх дослідженнях тлумачить економічний механізм господарювання як систему, яка складається із сукупності засобів, форм і методів економічного впливу на матеріальні інтереси працівників виробничої та невиробничої сфрер народного господарства. В числі основних складових економічного механізму господарювання вона виділяє ціноутворення, стимулювання праці, виробництва, якості продукції; економічні санкції; нормативну базу; критерії оцінки їх ефективності [3].

Економічний механізм, на думку багатьох авторів, $€$ сукупністю елементів впливу на матеріальні інтереси господарюючих суб'єктів народного господарства, основними 3 яких є: ціноутворення, планування, система оплати праці, фінансово-кредитний механізм, податкові платежі, економічне стимулювання і економічні санкції, комерційний розрахунок та система економічних нормативів $[13,5,8,4]$.

Тивончук С.О. і Тивончук Я.О. до складу цих елементів економічного механізму господарювання додають страхування ризиків діяльності бізнес-суб'єктів сфери АПВ та оцінку ефективності виробництва агропромислової продукції [14].

Дослідження характеру та складу організаційно-економічного механізму функціонування бізнес-суб'єктів аграрної сфери виробництва, дозволили визначити його як сукупність елементів організаційного блоку та економічного блоку у складі важелів зовнішньогосподарського і внутрішньогосподарського характеру, що справляють істотний вплив на результативність і конкурентоспроможність функціонування бізнес-суб'єктів аграрної сфери економіки (рис. 1).

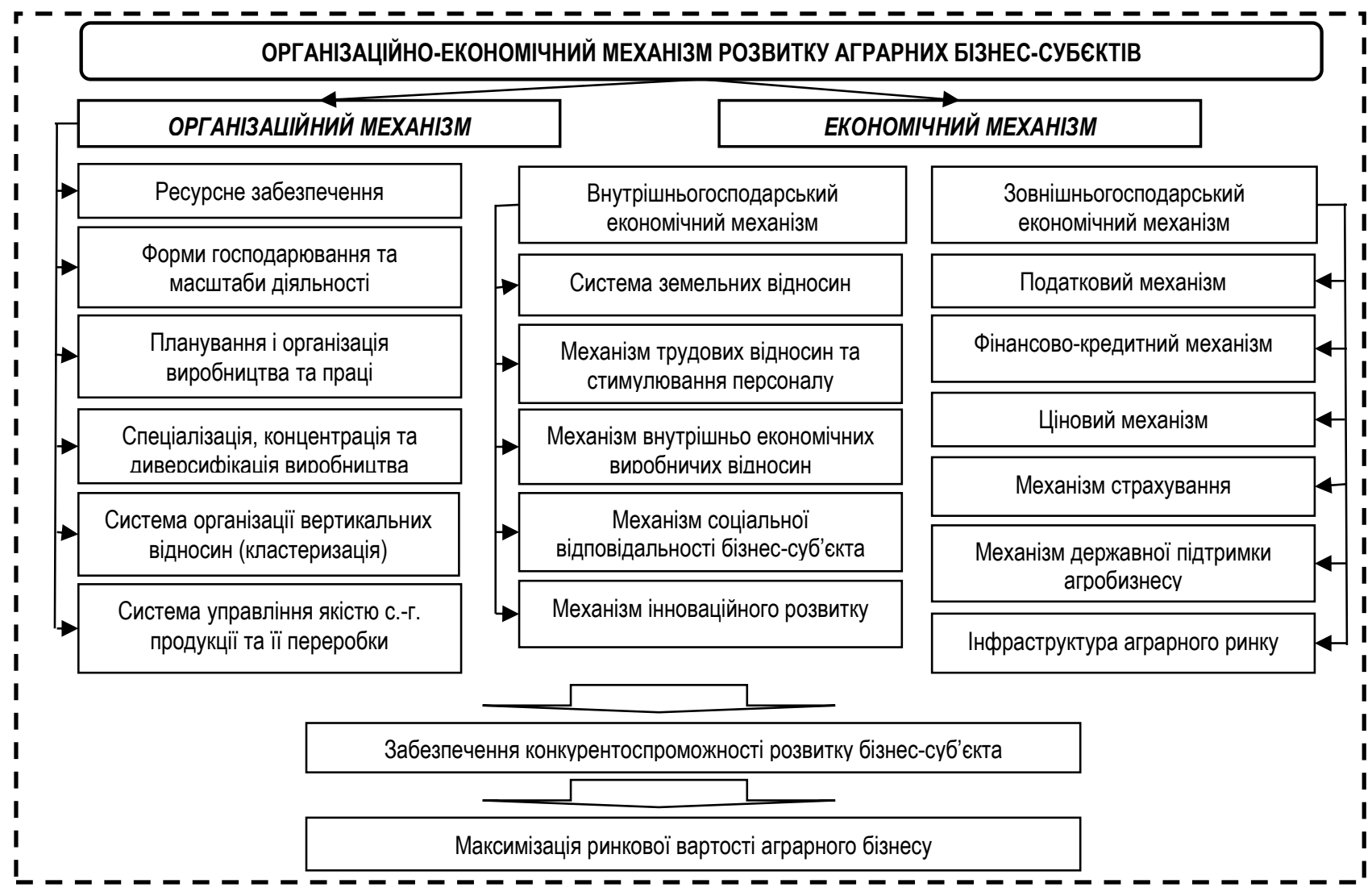

Рис. 1. Організаційно-економічний механізм розвитку бізнес-суб'єктів аграрного виробництва

Стратегічною метою дії організаційно-економічного механізму розвитку агроформувань, крім підвищення рівня конкурентоспроможності на ринку, є максимізація ринкової вартості аграрного бізнесу (за умов формування відповідних нормативно-правових та ринкових передумов).

У складі організаційно-економічного механізму госпо- дарювання вважаємо доцільним виділити сукупність інструментів зовнішнього характеру, які формуються під впливом курсу аграрної та економічної політики держави, а також дію важелів внутрішнього характеру, ефективність реалізації яких залежить безпосередньо від конкретного сільськогосподарського товаровиробника і $€$ першоосновою створення конкурентоспроможного національного аграрного сектору. 
3 огляду на реалії функціонування і розвитку підприємницьких структур аграрного сектору національної економіки та сучасні ринкові тенденції, вважаємо необхідним до складу елементів економічного механізму добавити таку складову, як механізм соціальної відповідальності аграрного бізнесу, який сьогодні постає активним інструментом підвищення рівня конкурентоспроможності бізнес-структур, збільшення ринкової частки та нарощування ринкової вартості бізнесу.
Вітчизняне аграрне виробництво сьогодні - висококонкурентний сектор національної економіки, у якому велика кількість товаровиробників виробляють практично однаковий спектр продукції. За даними Державної служби статистики України загальна кількість агроформувань у країні становить близько 45 тис. одиниць різних організаційно-правових форм господарювання, у розпорядженні яких знаходиться понад 22 млн. га сільськогосподарських угідь (табл. 1).

Таблиця 1

Кількість аграрних підприємств в Україні

\begin{tabular}{|c|c|c|c|c|c|c|c|c|c|}
\hline \multirow{2}{*}{ Категорії бізнес-суб'єктів } & \multicolumn{8}{|c|}{ Роки } & \multirow{2}{*}{$\begin{array}{l}\text { 2017p. до } \\
\text { 2010p., \% }\end{array}$} \\
\hline & 2010 & 2011 & 2012 & 2013 & 2014 & 2015 & 2016 & 2017 & \\
\hline Господарські товариства & 7769 & 7757 & 8235 & 8245 & 7750 & 7721 & 8700 & 6967 & 89,7 \\
\hline Приватні підприємства & 4243 & 4140 & 4220 & 4095 & 3772 & 3627 & 3752 & 3215 & 75,8 \\
\hline Виробничі с.-г. кооперативи & 952 & 905 & 848 & 809 & 674 & 596 & 738 & 448 & 47,0 \\
\hline Фермерські господарства & 41726 & 41488 & 34035 & 34168 & 33084 & 32303 & 33682 & 34137 & 81,8 \\
\hline Державні підприємства & 322 & 311 & 296 & 269 & 228 & 241 & 222 & 199 & 61,8 \\
\hline $\begin{array}{l}\text { Бізнес-суб'єкти інших фрорм господа- } \\
\text { рювання }\end{array}$ & 1481 & 1532 & 1781 & 1460 & 691 & 891 & 603 & 592 & 39,9 \\
\hline Разом & 56493 & 56133 & 49415 & 49046 & 46199 & 45379 & 47697 & 45558 & 69,6 \\
\hline
\end{tabular}

Джерело: складено автором за [12]

Аналіз складу і структури організаційних форм господарювання сільського господарства показує, що найбільш поширеними формами організації аграрного бізнесу сьогодні $€$ фермерські господарства (близько 75\%) та господарські товариства (15,3\%). При цьому, за останні роки спостерігається чітка тенденція до скорочення кількості бізнес-структур аграрної сфери, що зумовлено зростанням концентрації аграрного бізнесу та збільшенням кількості великих агрокомпаній (агрохолдингів). Так, проведене групування сільськогосподарських підприємств за розмірами сільгоспугідь показало, що із загальної кількості агроформувань близько $28 \%$ мають площу до 50га (мікроаграрні підприємства, переважно, фермерські господарства), 16,5\% - агропідприємства із розміром сільгоспугідь до 500 га, 11,5\% - підприємства із земельними масивами до 100 га. Частка великих агроформувань (площа сільгоспугідь від 4000 до 7000 тис га) становить 0,7\%, питома вага агрохолдингів (площа сільгоспугідь від 7000 до 10000 га) $-0,3 \%$.

Сільське господарство України сьогодні постає домінантним сектором національної економіки, який на чверть формує експортний потенціал країни, забезпечує продовольчу безпеку нації та демонструє стабільний рівень ефективності розвитку в порівнянні з іншими секторами національної економіки. За даними Державної служби статистики України, рівень рентабельності сільського господарства за 2017р. склав 18,7\% в порівнянні з аналогічним показником в цілому по економіці 8,8\% та за іншими видами економічної діяльності відповідно: промисловість - 1,9\%; будівництво - збитковість 2,0\%; оптова та роздрібна торгівля - 5,0\%; транспорт, складське господарство, поштова та кур'єрська діяльність збитковість на рівні 3,5\%; фінансова та страхова діяльність 14,3\%. Абсолютний показник розміру чистого прибутку відповідно по галузях у 2017р. склав: сільське господарство - 78,5 млрд. грн., промисловість - 56,1 млрд. грн., будівництво - 5,0 млрд. грн. збитку, оптова та роздрібна торгівля - 25,8 млрд. грн., транспорт, складське господарство, поштова та кур'єрська діяльність - збиток 16,8 млрд. грн., фінансова та страхова діяльність - 16,8 млрд. грн. [2].

Структурні зрушення у сільському господарстві України за останні роки спричинили формування чіткої тенденції укрупнення агарного бізнесу та утворення великих агрокорпорацій. Сьогодні найбільш крупними агрохолдингами України є: UkrLandFarming (570 тис. га), Kernel (550 тис. га), APGroup (400 тис. га), Міронівський хлібопродукт (370 тис. га), «Астарта-Київ» (245 тис. га), «Мрія» (165 тис. га), ІМК (136 тис га), «AgroGeneration» (120 тис. грн.), «УкрпромінвестАгро» (116,5 тис га), «Агротон», «АСТ» (по 110 тис га), «Нібулон» (83 тис га) та інші з площею менше 80 тис. га («АгроBiста», «Сварог Вест груп», «Світанок», «VitAgro», «Агротрейд», Південна Аграрно-експортна компанія тощо) [16].

Частка великих агрокорпорацій у структурі експорту пшениці становить близько 60-65\%. Саме на агрохолдинги приходиться найбільша частка інвестиційних і фінансових потоків, які спрямовуються у аграрний бізнес країни [10]. Агрохолдинги сьогодні мають більше можливостей впроваджувати у виробництво інноваційні технології виробництва й управління в порівнянні з середніми та малими аграрними формуваннями. Саме на прикладі великих агрокорпорацій в сучасних умовах реалізується на практиці дія практично всіх складових організаційно-економічного механізму розвитку аграрних бізнес-структур. Передумовою для цього постає значна концентрація капіталу та високій рівень агроменеджменту.

Разом з тим, ефективний розвиток аграрної сфрери, неодмінною складовою якої є динамічний розвиток сільських територій, неможливий без функціонування малого та середнього бізнесу, організаційно-економічний механізм розвитку яких сьогодні виявляється більш проблемним, ніж в крупних агрокорпораціях. Так, на рівні середніх та малих агроструктур практично відсутня дія таких елементів організаційного блоку, як: планування виробництва, організація вертикальних інтегрованих структур, система управління якістю на виробництві. Серед елементів економічного блоку найбільш проблемними постають: державна підтримка доходів невеликих агровиробників, механізм страхування, монопольний вплив посередницьких структур на ринку агропродукції. Практично відсутні в системі внутрішнього економічного механізму малих агропідприємств такі елементи, як: механізм внутрішньо економічних відносин між структурними підрозділами, меха-

Вісник Сумського національного аграрного університету

Серія «Економіка і менеджмент», випуск 1 (79), 2019 
нізм соціальної відповідальності, слабким є інноваційний механізм розвитку невеликого аграрного бізнесу.

Таким чином, основні шляхи удосконалення дії організаційно-економічного механізму в практичній діяльності аграрних бізнес-суб'єктів, зокрема, невеликих за розмірами, в сучасних умовах мають бути зосереджені у спектрі зміни парадигми внутрішньогосподарського управління у напрямі пошуку та імплементації ефективних методів і інструментів впливу на ресурси, зокрема, людський капітал, систему організації і реалізації економічного інтересу структурних одиниць агроформувань, підвищення рівня соціальної відповідальності бізнесу та важелів активізації інвестиційно-інноваційних способів ведення господарської діяльності. Сукупність цих дій внутрішньоекономічного характеру, на думку експертів, формує до 70\% успіху агробізнесу на ринку. Інші 30\% конкурентоспроможності аграрних підприємств визначаються ефективністю дії елементів зовнішньогосподарського економічного механізму [11].

Висновки та перспективи подальших наукових досліджень. Вітчизняний аграрний бізнес функціонує у складних конкурентних умовах зовнішнього та внутрішнього економічного середовища, сукупність та органічне поєднання яких формують склад елементів організаційно-економічного механізму розвитку агропідприємств. Дослідження показали, що залежно від характеру виникнення та дії всі складові економічного механізму доцільно поділити на два основних блоки: елементи внутрішньогосподарського та зовнішньогосподарського економічного механізму. Головною метою дії організаційно-економічного механізму на практиці має стати нарощування ринкової вартості аграрного бізнесу.

В аграрній сфрері за останні роки спостерігається чітка тенденція на укрупнення аграрного бізнесу і концентрацію аграрного капіталу, результатом чого постає збільшення кількості агрокорпорацій, на прикладі яких реалізується дія практично всіх елементів організаційно-економічного механізму господарювання в аграрній сфері. Сільське господарство України сьогодні - один з секторів, який демонструє позитивну і сталу динаміку ефективності господарської діяльності. 3 метою збереження такого тренду та покращення показників діяльності в подальшому необхідним є практична реалізація всіх елементів організаційно-економічного механізму на рівні малих та середніх аграрних формувань. Основна увага агроменеджменту при цьому має концентруватись в напрямі удосконалення управління сукупністю елементів внутрішньогосподарського економічного механізму. Перспективами подальших наукових досліджень в даному контексті постає обґрунтування дієвих інструментів і важелів всіх складових організаційно-економічного механізму розвитку аграрного бізнесу незалежно від його розмірів.

\section{Список літератури:}

1. Бутенко В. М. Організаційно-економічний механізм підвищення ефективності соціальної сфери села. Вісник аграрної науки Причорномор'я. 2004. Вип. 2(26). С. 38- 40.

2. Діяльність суб'єктів господарювання. 2017р.: стат. зб. /Держ. служба статистики України. URL: http://ukrstat.gov.ua/druk/publicat/kat_u/2018/zb/11/zd_2018.pdf

3. Домахіна О.В. Формування механізму господарювання у реформованих сільськогосподарських підприємствах: дис... канд. екон. наук: 08.07.02. Харків, 2000. 22 с.

4. Еременко-Григоренко О. А. Организационно-экономический механизм управления хозяйственной деятельностью предприятия : автореф. дис... канд. экон. наук: 08.06.0. Донецк, 1999. 31 с.

5. Зиновьев Ф.В. Механизмы хозяйствования (терминологический аппарат). Симферополь: Таврия, 2000. 111с.

6. Зинченко Т.Є. Інституціональний механізм раціоналізації землекористування агломераційних систем. Агросвіт. 2012. № 9. С. 65-71.

7. Лисенко Ю., Єгоров П. Організаційно-економічний механізм управління підприємством. Економіка України. 1997. № 1. C. $86-87$. $328 \mathrm{c}$.

8. Мостенська Т.Л. Економічний механізм функціонування молочної промисловості України. Київ: УдУХТ, 2001.

9. Пархомець М.К., Гудак В.В. Організаційно-економічний механізм забезпечення дохідності сільськогосподарських підприємств: теорія, методика, практика: монографія. Тернопіль, ТНЕУ. 2014. 256с.

10. Постол А.А. Розвиток великих аграрних підприємств: механізми та інструментарій: монографрія. Харків: «Смугаста типографія», 2018. 289c.

11. Саблук П.Т. Економічний механізм АПК у ринковій системі господарювання. Економіка АПК. 2007. № 2. С. 3-10.

12. Сільське господарство України. 2017р.: стат. зб. ДДерж. служба статистики України. URL: http://ukrstat.gov.ua/druk/publicat/kat_u/2018/zb/09/zb_sg2017

13. Стельмащук А. М. Економічний механізм прискорення інтенсифікації виробництва в АПК. Київ: Урожай, 1990. $155 \mathrm{c}$.

14. Тивончук С.О., Тивончук Я.О. Організаційно-економічний механізм активізації інноваційного розвитку агропродовольчого комплексу України в ринкових умовах (концептуальні та методичні положення). Економіка АПК. 2013. № 7. С. 62-69.

15. Ткачук B.І. Організаційно-економічний механізм у сільськогосподарських підприємствах та його моделювання. Агросвіт. 2015. № 23. С. 17-25.

16. Топ-100 латифундистов Украины. URL: https://latifundist.com/rating/top100\#

Kryukova I., Dr, Associate Professor, Odessa State Agrarian University (Odessa, Ukraine) Organizational and economic mechanism of development of business subjects of agrarian production

The existing methodological approaches to the interpretation of the content of the category "organizational and economic 
mechanism" are considered in the article. The determination of the essence of the organizational and economic mechanism of development of agrarian business has been proposed. The composition of the main elements of the internal and external economic mechanism of the economic mechanism is supplemented here. The general assessment of the current state of development of the agricultural sector was carried out. The modern trends in the capitalization of agribusiness, and an increase in the number and size of the business of domestic agricultural holdings are presented. The main directions of improving the management of business entities through the elements of the organizational and economic mechanism of their development have been defined.

Key words: organizational and economic mechanism, agricultural business, business entities, agricultural holdings, agriculture, rural areas, the value of the agricultural business.

Дата надходження до редакції: 05.12.2018 р. 